\title{
Characterization of Local Algerian Population of Rabbit: Factors Influencing Fetal and Placental Development
}

\author{
Rafik Belabbas ${ }^{1}$, ImenIlès ${ }^{2}$, Hacina Ain Baziz ${ }^{2}$, Michel Theau-Clément ${ }^{3}$, Ali Berbar ${ }^{1}$, Zoubida Boumahdi ${ }^{1}$, \\ Ibitessem Boulbina ${ }^{2}$, Nadia Benali ${ }^{2} \&$ Soraya Temim $^{2}$ \\ ${ }^{1}$ University of Saad Dahleb Blida, Biotechnology Laboratory of Animal Reproduction, Blida, Algeria \\ ${ }^{2}$ Laboratory of research "Health and Animal Production", National Veterinary School, Algeria \\ ${ }^{3}$ INRA, UR631 SAGA, F-31326 Castanet-Tolosan, France \\ Correspondence: Belabbas Rafik, University of Saad Dahleb Blida, Biotechnology Laboratory of Animal \\ Production, Blida, Algeria. E-mail: rafikbelabbas@yahoo.fr
}

\author{
Received: August 13, 2012 Accepted: September 24, 2012 Online Published: February 5, 2013 \\ doi:10.5539/jas.v5n3p76 URL: http://dx.doi.org/10.5539/jas.v5n3p76
}

\begin{abstract}
The objective of our work was to study the effect of parity the parity of the does, the intra uterine position and vascularization of the fetuses and their number per horn on, available uterine space and placentae development in the rabbit at two stages (nulliparous and primiparous). To this aim, twenty rabbit does of locally Algerian population were distributed in two groups of 10 each (nulliparous and primiparous). The does were mated and slaughtered on $24^{\text {th }}$ day of gestation. In the group of fetuses receiving poor blood supply ( $\leq 4$ blood vessels), the individual weight and the crown-rump were lower $(-24.4$ and $-12.6 \%$ respectively; $\mathrm{p}<0.05)$ compared to those with higher number of blood vessels $(\geq 5)$. The intra uterine position affects significantly the individual weight of maternal placenta and the heavier one was located in the oviduct. Significant interaction between parity and the number of blood vessels was recorded for the individual weight of fetal placenta $(p<0.05)$. Available uterine space was lower in the primiparous, in the middle position and in the class of fetuses with lower blood supply. In primiparous, the horns with 5 or 6 fetuses presented a better vascularization than those with the same number in nulliparous $(+25 \%)$. The fetal weight and crown-rump decreased when the number of fetus per horn increased $(p<0.05)$. A significant interaction was recorded between the parity and the number of fetus per horn for the weight of maternal placenta ( $+15 \%$ and $+30 \%$ respectively in the horn within 3 or 5 fetuses in nulliparous; $p<0.05$ ). Available uterine space was greater in nulliparous compared to the primiparous and decreased when the number of fetus per horn increased. These results suggest that available uterine space and fetal development at $24^{\text {th }}$ of pregnancy are affected respectively by parity of the rabbit and the vascularization of the implantation site.
\end{abstract}

Keywords: rabbits, parity order, placenta, fetus, available uterine space

\section{Introduction}

The weight and corporal composition of the rabbit kits at birth play an important role on their survival and development before weaning and thereafter during all stages of their life. Szendrö et al. (1996), Ferguson et al. (1997) studied the influence of birth weight on ulterior performances of rabbits kits up to 12 weeks of age. Higher weight at birth (45.2 vs $63.8 \mathrm{~g}$ (Szendrö et al., 1996) and 57 vs $70 \mathrm{~g}$ (Vasquez and al., 1997) results in a higher weight at 21 days of age (309vs $389 \mathrm{~g}$ and $328 v s 368 \mathrm{~g}$, respectively) and at 12 weeks of age (2436 vs $2887 \mathrm{~g}$ and 3003 vs $3101 \mathrm{~g}$, respectively). According to Szendrö et al. (1996), the mortality rate is lower (-12.6\%) in the class of rabbits with a birth weight between 60 and $69 \mathrm{~g}$ compared to rabbits kits weighing between 40 to $49 \mathrm{~g}$. The weight of rabbit kits at birth is influenced by several factors during the pregnancy period (litter size, kindling number, physiological status, nutrition, intra uterine position and vascularization of the fetuses). Indeed, the average individual birth weight increase when the litter size decrease, as the degree of nutrient supply per foetus is more favorable in does carrying fewer young (Duncan, 1969; Lebas, 1982; Garcia-Ximenez \& Vicente, 1993; Bolet, 1994; Bolet et al., 1996). The growth of the fetuses is influenced also by the parity order of the doe. The progeny of multiparous is substantially heavier than that of the offspring of nulliparous (Baselga et al., 1992; Farghaly, 1996; Eiben et al., 1996; Szendro et al., 1998; Belabbas et al., 2011). In his study, Parigi-Bini and Xiccato (1993) reported that the birth weight was 6 to $10 \%$ lower in nulliparous compared to multiparous rabbit does. As the first insemination of the females is realized when they reach 75 to $80 \%$ of their adult, a considerable 
proportion of the nutrients available during their first pregnancy is still being affected for the development of their own tissues, to the detriment of the fetal growth. Otherwise, the production of milk in the nursing does affects negatively the growth of the fetuses. Fortun et al. (1993) had compared the suckling does with non-suckling controls and observed a $20 \%$ difference in the fetal weight at 28 days, despite the fact in the suckling does; the feed intake was $78 \%$ higher. The effect of lactation increases when the quantity of milk production by female is higher. In the same way, Fortun et al. (1994) and Fortun-Lamothe (1998) found a low fetal weight $(p<0.05)$ rabbits does which were subjected to different degrees of feed restriction. In non-suckling primiparous does, a feed restriction (75\% of ad libitum) decrease significantly the fetal weight (-24\%). The weight of fetuses is related also to their position in the uterine horn.

Indeed, the heaviest fetuses are situated in the oviduct position and the lightest fetuses developed in the mid uterine position (Duncan, 1969; Bruce \& Abdul-Karim, 1973; Poigner et al., 2000). Finally, the number of blood vessels arriving at each implantation site, seems to have an important effect on fetal and placental development, as well as on fetal survival (Mocé et al., 2004; Argente al., 2003). Poor blood supply is associated with lower fetal and placentae weight and higher probability of death (Argente et al., 2003). These factors were studied generally for the same parity. The aim of this experiment was to study on nulliparous and primiparous does, the effect of the number of fetus per horn, the intra uterine position and vascularization, on available uterine space per fetus, placental and fetal development in the local Algerian rabbits.

\section{Material and Methods}

\subsection{Animals}

Rabbits used in this experience came from an experimental farm of the High National Veterinary School (Alger's). Twenty rabbit females of local Algerian population were used in this work (10 nulliparous and 10 not-lactating primiparous). The criteria of selection were the age (4.5 months for nulliparous and 7 months for primiparous), the average live weight at mating ( $2576 \pm 59$ and $3188 \pm 155 \mathrm{~g}$ respectively for nulliparous and primiparous females). All the primiparous nursed during their first lactation the same number of kits (6-7), in order to avoid variability for this parameter (we used non lactating primiparous after weaning). Females were caged individually and had free access to pelleted commercial diet (15.89\% crude protein, $9.08 \%$ crude fiber, $3.75 \%$ fat and $6.91 \%$ of ash) and water.

\subsection{Experimental Design and Measurement}

Nulliparous females were presented to a male for the first time when they were 4.5 months old. For primiparous, the mating was made after weaning performed at 35 days to avoid the ominous effect of lactation on pregnancy. The pregnancy status was tested by abdominal palpation of the doe 12 days after mating and all females were pregnant. The twenty rabbit does were slaughtered on $24^{\text {th }}$ day, and immediately after, their genital tract was removed and dissected to evaluate the different parameters.

To locate the implantation site of each fetus, an external examination of the uterine horn was made. The number of blood vessels that receive each live fetus was calculated in order to evaluate the vascular supply according to Argente et al. (2003). Live fetuses were classified as receiving less-than or equal to 4 blood vessels $(\leq 4)$ and greater-than or equal to 5 blood vessels $(\geq 5)$. On forty horn, only thirty seven $(n=37)$ uterine horns were selected. Three horns were excluded: two contained only a single fetus and one horn was empty. Afterward, from both of uterine horns, the mesometrium was trimmed. For each gravid uterine horn, fetuses were observed. According to their status, the fetuses were classified as alive or dead. In the implantation site, the presence of maternal placenta only or within atrophic fetal placenta was also considered as a dead fetus (Argente et al., 2003). There were 55 and 84 lives fetuses in nulliparous and primiparous respectively. By horn, the number of dead fetuses was lower (3 fetuses in primiparous does). Placental membranes and fluids were removed. The position of each fetus was recorded by starting on the ovarian end. Three uterine positions were considered: oviduct (the first fetus in the horn near ovary), middle (fetuses implanted in middle of uterine horn) and cervix (the last fetus in the uterine horn nearest cervix). For each uterine horn, fetuses, maternal and fetal placenta were separated and individually weighted and fetal crown-rump was calculated.

Availability of uterine space for each fetus was estimated as in Argente et al. (2008). For each fetus it was calculated as the length of maternal placenta plus half of the distance from its right and left boundaries to the nearest placenta. For the fetuses implanted at the beginning of the cervix, available uterine space was calculated as the length of maternal placenta plus the distance from the boundary of the placenta to the beginning of the cervix, plus one-half of the distance from the other boundary to the nearest placenta. For the embryos located in the oviduct position, similar procedure was used. 


\subsection{Statistical Analyses}

The data were analyzed using an analysis of variance (ANOVA 3) taking into account the fixed effect of the parity ( 2 levels), vascular supply ( 2 levels) and intra uterine position (3 levels) as well as their interactions. The effect of the number of fetus per horn among parity order of the dam on different parameters measured was analyzed using analysis of variance (ANOVA 2) taking into account the fixed effect of parity ( 2 levels) and the number of foetus per horn (4 levels) as well as their interactions. Analyses were performed using the program Statview (Abacus Concepts 1996, Inc., Berkeley, CA94704-1014, USA).

\section{Results and Discussion}

The weight and the crown-rump of the fetus were not significantly influenced by the parity order of the dam and the intra uterine position of the fetus (Table 1). However, these traits were significantly influenced by the number of the blood vessels reaching each implantation site $(\mathrm{p}<0.001)$. Indeed, the individual weight and the crown-rump of the fetus were 24.4 and $12.6 \%$ lower respectively in the group of the fetuses with placentas receiving poor blood supply ( $\leq 4$ blood vessels) compared to those receiving higher number of blood vessels $(\geq 5$ ) (Table 2). Similar results were obtained in rabbit by Argente et al. (2008) at $18 \mathrm{~d}$ of pregnancy and Bruce and Abdul-Karim (1973) and Mocé et al. (2004) at 28 day. In mice, Wirth-Dzieciolowska (1987) obtains the same result in the late stages of gestation. The increase in the number of blood vessels reaching the implantation site is associated with a better nutrient supply and consequently, a better fetal development (Argente et al., 2003).

Table 1. Effect of parity, intra uterine position and vascularization on individual weight of fetus and its placentas, fetal crown-rump length and available uterine space per fetus (mean $\pm \mathrm{SD}$ )

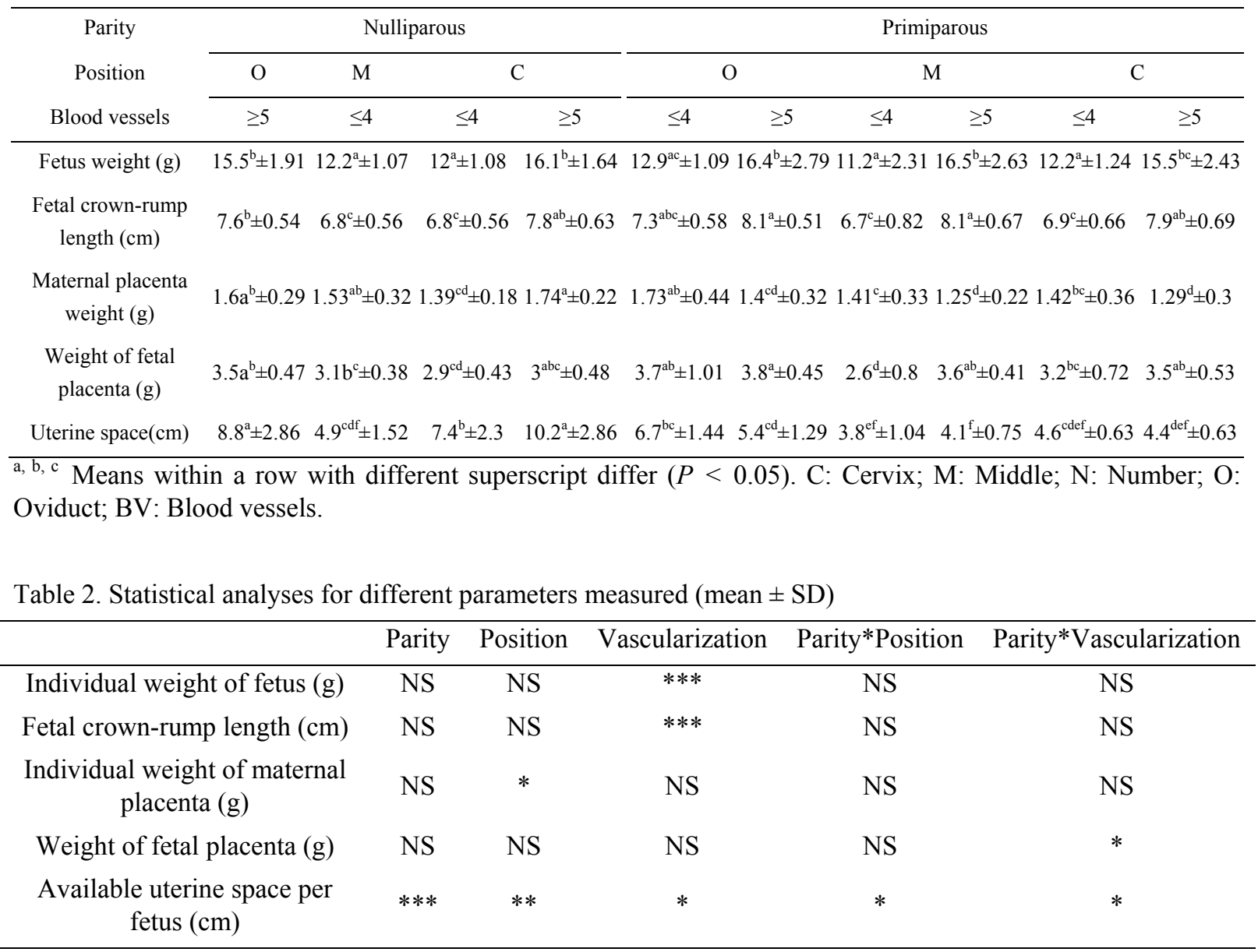

$* \mathrm{p}<0.05 ; * * \mathrm{p}<0.01 ; * * * \mathrm{p}<0.001 ;$ NS: non significant $(\mathrm{p}>0.05)$.

Table 1 shows that the intra uterine position affects significantly the individual weight of the maternal placenta $(\mathrm{p}<0.05)$. The heavier maternal placenta was located in the oviduct uterine position, weighting $12 \%$ and $8,6 \%$ higher than those in middle of uterine position and cervix position respectively. This agrees with the findings of 
Duncan (1969), Bruce and Abdul-Karim (1973) and Argente et al. (2003) in rabbits and Vallet and Christenson (1993) in pigs.

On the one hand, previous studies showed in the rabbits and in the pigs, that the fetuses in the mid-uterine position seem to have higher competition for availability of uterine space than fetuses near the oviduct (this smaller uterine space could reduce placental growth) (Bruce \& Abdul-Karin, 1973; Webel \& Dziuk, 1974; Wu et al., 1993).

On the other hand, the fetuses near the oviduct had a greater blood flow at the end of gestation therefore better development of placentae (Duncan, 1969). Santacreu et al. (1994) determined the level of blood supply to individual fetuses on the basis of the number of veins in their vicinity. They ascertained that fetuses at the bottom of the uterus were better irrigated, irrigation being less efficient in those situated slightly higher.

Significant interaction between parity order and the vascularization of implantation sites was recorded for the individual weight of fetal placenta. In primiparous, we observed that the fetuses with higher number of blood vessels showed heavier fetal placenta.

At 28 days of pregnancy, Mocé et al. (2004) reported that the number of blood vessels received at each implantation site significantly affects the weight of fetal placenta, and the higher number of blood vessels is related to a better nutrient supply and consequently to a better development of placenta.

Our data shows that availability of uterine space was higher in the nulliparous compared to the primiparous does. The larger implanted embryos observed in primiparous does $(8.4 v s 5.5 ; \mathrm{p}<0.05)$ seems to be responsible of this reduction in availability of uterine space. Similarly, Argente et al. (2008) have shown that available uterine space per implanted embryo decreased when the number of implantation sites per uterine horn increased.

Present data shows that the fetuses near the oviduct had higher available uterine space than those in middle of uterine horn or near the cervix. This result is probably related to the less competition for available uterine space and a better vascular supply (Duncan, 1969; Bruce \& Abdul-Karim, 1973; Argente et al., 2003). Likewise, the increase in blood supply was associated with a higher availability of uterine space. Argente et al. (2008) reported that a higher availability of uterine space would allow more blood vessels to reach each implantation site.

The effect of both parity and the number of fetus per horn on the number of blood vessels, fetal and placental development and available uterine space are shown in Table 3 . The number of blood vessels was not significantly influenced by either parity or the number of fetus per horn but the interaction between those two factors was significant ( $\mathrm{p}<0.001$, Table 3). In primiparous, the horns with 5 or 6 fetuses present a higher number of blood vessels than those with the same number in nulliparous $(+25 \%)$. As regards the relationships between parity order and reproductive traits, our results agreed with existing literature describing best development of genital tract at primiparous stage (Parigi Bini et al., 1989; Bolet et al., 1996; Boumahdi et al., 2009) and in turn a better vascularization (Argente et al., 2008).

Table 3. Effect of crowding of the uterine horn, on individual number of blood vessels, weight of fetus, fetal crown-rump length and available uterine space per fetus (mean $\pm \mathrm{SD}$ )

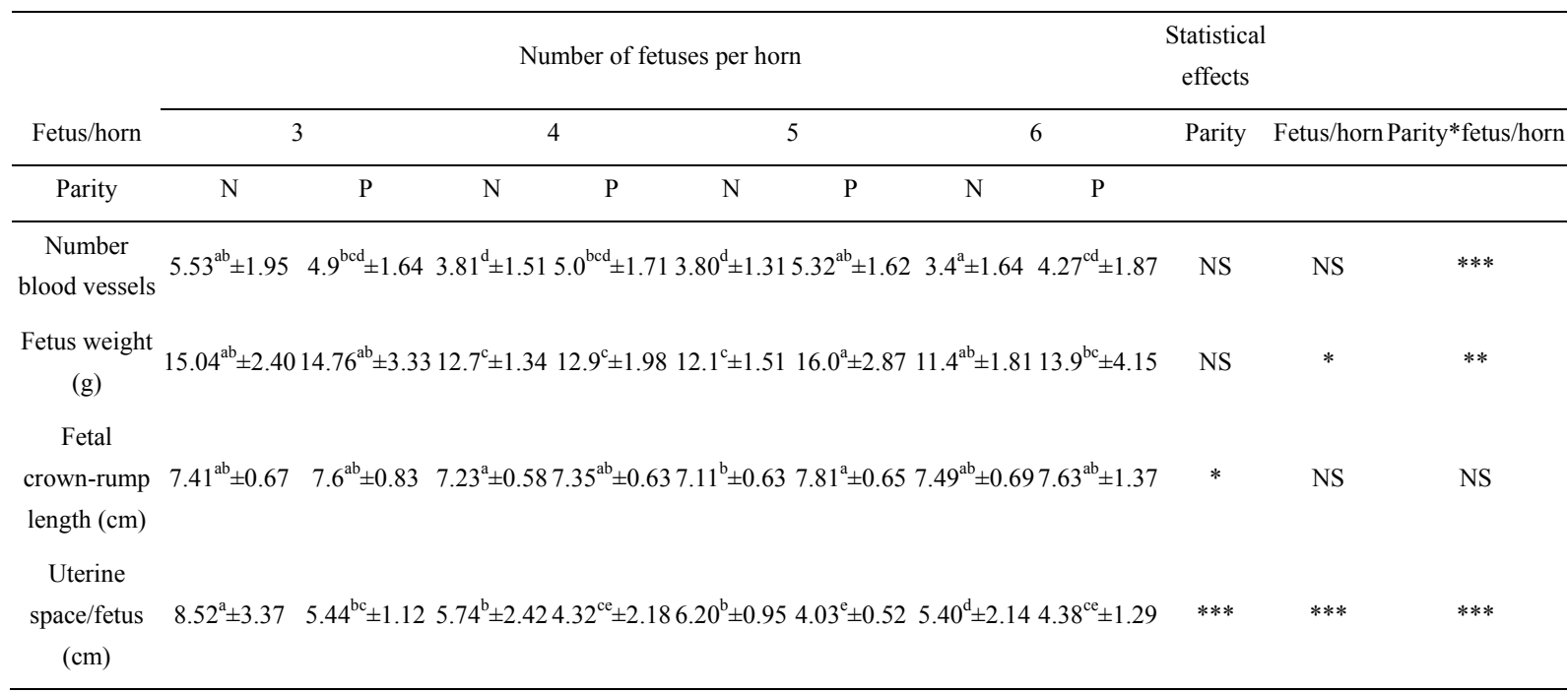

N: Nulliparous; P: Primiparous, Means within a row with different superscript differ $(\mathrm{P}<0.05)$. 
The fetal weight and fetal crown-rump decreased when the number of fetus per horn increased $(p<0.05)$ and when the horn contains 5 fetuses, the fetal crown-rump and weight were reduced in nulliparous compared to primiparous does (- 9\% and - 24\% respectively). This is in agreement with previous studies (Argente et al., 1996; Hamilton et al., 1997; Zerrouki et al., 2005; Fellous et al., 2012). A significant interaction between the parity and the number of fetus per horn was recorded for the weight of maternal placenta. The maternal placenta in the horn within 3 or 5 fetuses were higher in the nulliparous compared to the primiparous rabbits $(+15 \%$ and $+30 \%$; $<0.05$ respectively). The low maternal placenta recorded in primiparous is related to the increase of implanted embryos on the one hand and the reduction of availability of uterine space on the other hand. As Argente et al. (2008) reported, overcrowding of uterine horn is associated to a lower availability of uterine space and in turn, a reduction of fetal and placentae weight. The interaction between parity and the number of fetus per horn was significant $(\mathrm{p}<0.001)$ for available uterine space. Indeed, available uterine space was low in primiparous compared to the nulliparous and reduced in the horns with low number of implanted embryos. In primiparous, a lower availability of uterine space is related to a greater number of implanted embryos.

\section{Conclusion}

In conclusion, the weight and crown rump of fetus at $24^{\text {th }}$ day of pregnancy in the locally Algerian does are related to the vascularization of their implantation sites. The fetuses with higher number of blood vessels presented the best performances. Available uterine space per fetus was affected by the parity order of the rabbits, vascularization and intra uterine position of fetus. Indeed, it was greater in nulliparous compared to the primiparous rabbit related to a higher number of implanted embryos observed in primiparous, decrease when the number of blood vessels reaching each implantation site increase and reduces in the mid-uterine position compared to the other positions (oviduct and cervix). The individual weight of maternal placenta was lower in middle position consequence of higher competition for implantation and for available uterine space between fetuses at this localization. The number of fetus per horn influenced the individual weight of maternal placenta and availability of uterine space. Whatever the number of fetuses per horn, the nulliparous females showed heavily maternal placenta and greater available uterine space than primiparous females.

\section{Acknowledgments}

We thank Doctor Argente M.J. from the Universidad Miguel Hernández de Elche and Professor Blasco A. from the Universidad Politécnica de Valencia (Spain) for the experimental design and the methods.

\section{References}

Argente, M. J., Sanchez, M. J., Santacreu, M. A., \& Blasco, A. (1996). Genetic parameters of birth weight and weaning weight in ovariectomised and intact rabbit does (pp. 237-240). In Proc. $6^{\text {th }}$ World Rabbit Congress, World Rabbit Science Association, France, Toulouse.

Argente, M. J., Santacreu, M. A., Climent, A., \& Blasco, A. (2003). Relationships between uterine and fetal traits in rabbit selected on uterine capacity. J. of Anim. Sci., 8, 1265-1273. Retrieved from http://jas.fass.org/content/81/5/1265.full.pdf + html

Argente, M. J., Santacreu, M. A., Climent, A., \& Blasco, A. (2008). Effect of intra uterine crowding on available uterine space per fetus in rabbits. Livestock Sci, 114, 211-219. http://dx.doi.org/10.1016/j.livsci.2007.05.008

Baselga, M., Gómez, E., Cifre, P., \& Camacho, J. (1992). Genetic diversity of litter size traits between parities in rabbits. J. Appl. Rab. Res., 15, 198-205.

Belabbas, R., AinBaziz, H., Ilès, I., Zenia, S., Boumahdi, Z., Boulbina, I., \& Temim, S. (2011). Etude de la prolificité et de ses principales composantes biologiques chez la lapine de population locale algérienne (Oryctolagus cuniculus). Livestock Res. For Rur. Develop, 23, 3. Retrieved from http://www.lrrd.org//rrd23/3/bela23061.htm

Bolet, G. (1994). Effet du nombre de foetus par corne uterine et de la taille de portée à la naissance sur le poids des lapereaux jusqu'à 11 semaines, après standardisation des portées (pp. 127-135). $6^{\text {èmes }}$ Journées de Recherche Cunicole, INRA, La Rochelle, France, 1.

Bolet, G., Esparbie, J., \& Falieres, J. (1996). Relations entre le nombre de foetus par corne utérine, la taille de portée à la naissance et la croissance pondérale des lapereaux. Annales de Zootechnie, 45, 185-200. http://dx.doi.org/10.1051/animres:19960207

Boulbina, I., AinBaziz, H., Ilès, I., Belabbas, R., Benali, N., Zenia, S., \& Temim, S. (2012). Effet de la saison de naissance sur l'âge d'entrée en puberté et les caractéristiques de la semence chez le lapin mâle de population 
locale algérienne (Oryctolagus Cuniculus). Livestock Res. for Rur. Dev., 24(1). Retrieved from http://www.lrrd.org/lrrd24/1/boul24011.htm

Boumahdi, Z., Belabbas, R., Theau-Clément, M., Bolet, G., Brown, P. \& Kaidi, R. (2009). Behavior at birth and anatomo-histological changes studies of uteri and ovaries in the post-partum phase in rabbits. Euro. J. of Sci. Res., 34(4), 474-484. Retrieved from http://www.eurojournals.com/ejsr\%2034\%204.htm

Bruce, N. W., \& Abdul-Karim, R. W. (1973). Relationships between fetal weight, placental weight and maternal placental circulation in the rabbit at different stages of gestation. $J$. of Reprod and Fert, 32, 15-24. http://dx.doi.org/10.1530/jrf.0.0320015

Duncan, S. L. B. (1969). The partition of uterine blood flow in the pregnant rabbit. J. of Phy., 204, 421-433. Retrieved from http://jp.physoc.org/content/204/2/421.full.pdf + html

Eiben, Cs., Kustos, K., Kenessey, A., Terenyi, Y., Viràg, G. Y., \& Szendrö, Z. S. (1998). Effect of different of different feed restrictions during rearing on the does performance (Preliminary results) (pp. 63-69). in Proc. 10. Nyultenyésztési Tudomànyos Nap, Kaposvàr in Hung.

Farghaly, H. M. (1996). Analysis of incidence of pre and post mature gestations in rabbit populations (pp. 273-277). In Proc. $6^{\text {th }}$ World Rabbit Congress, World Rabbit Association Toulouse, France.

Fellous, N., Reguig, K., AinBaziz, H. (2012). Evaluation des performances zootechniques de reproduction des lapines de population locale Algérienne élevées en station expérimentale. Livestock Res. for Rur. Dev., 24(3) 2012. Retrieved from http://www.lrrd.org/lrrd24/3/fell24051.htm

Ferguson, F. A., Lukefahr, S. D., \& McNitt, J. I. (1997). Preweaning variables influence on market traits in rabbits. J. of Anim. Sci, 75, 611-621. Retrieved from http://jas.fass.org/content/75/3/611.full.pdf + html

Fortun, F., Prunier, A., \& Lebas, F. (1993). Effects of lactation on fetal survival and development in rabbit does mated shortly after parturition. J. Anim. Sci, 71, 1882-1886. Retrieved from http://jas.fass.org/content/71/7/1882.full.pdf + html

Fortun, L., Prunier, A., Etienne, M., \& Lebas, F. (1994). Influence of the nutritional deficit on fetal survival and growth and plasma metabolites in rabbit does. Reprod. Nut Develop, 34, 201-211. Retrieved from http://rnd.edpsciences.org/index.php?option=com_toc\&url=/articles/rnd/abs/1994/03/contents/contents.html

Fortun-Lamothe, L. (1998). Effect of pre-mating energy intake on reproductive performance of rabbit does. Animal Sci, 66, 263-269. http://dx.doi.org/10.1017/S1357729800009048

Garcia-Ximenez, F., \& Vicente, J. S. (1993). Limiting effects of uterine crowding on the number and weight of live pups. Reproduction Nut. Develop, 33, 69-73. Retrieved from http://rnd.edpsciences.org/index.php?option=com_toc\&url=/articles/rnd/abs/1993/01/contents/contents.html

Hamilton, H. H., Lukefahr, S. D., \& McNitt, J. I. (1997). Maternal nest quality and its influence on litter survival and weaning performance in commercial rabbits. J. of Anim. Sci., 75, 926-933. Retrieved from http://jas.fass.org/content/75/4/926.full.pdf + html

Lebas, F. (1982). Influence de la position in utero sur le développement corporel des lapereaux (pp. 161-166). $3^{\text {émes }}$ Journées de la Recherche Cunicole, 8-9 Décembre 1982, INRA, Paris.

Mocé, M. L., Santacreu, M. A., Climent, A., \& Blasco, A. (2004). The effect of divergent selection for uterine capacity on fetal and placental development at term in rabbits: Maternal and embryonic genetic effects. $J$. of Anim. Sci., 82, 1046-1052. Retrieved from http://jas.fass.org/content/82/4/1046.full.pdf + html

Parigi-Bini, R., Xiccato, G., \& Cinetto, M. (1989). Influenza dell' intervallo partoaccoppiamento sulle prestazioni riproduttive delle coniglie fattrici. Coniglicoltura, 7, 51-57.

Parigi-Bini, R., \& Xiccato, G. (1993). Recherches sur l'interaction entre alimentation, reproduction et lactation chez la lapine. World Rab. Sci., 1, 155-161.

Poigner, J., Szendro, Z. S, Lévai, A., Biró-Németh, E., \& Radnai, I. (2000). Weight of new-born rabbits in relation to their number and position within the uterus in unilaterally ovariectomised does. $7^{\text {th }}$ World Rabbit Congress, World Rabbit Science Association, Valencia, Spain, 231-237.

Santacreu, M. A., Climent, A., Argente, M. J., \& Blasco, A. (1994). Caractéristiques, irrigation sanguine et survie des fretus dans deux lignées de lapin sélectionnées de façon divergent pour l'efficacité utérine (pp. 247-253). $6^{\text {èmes }}$ Journées de Recherche Cunicole, INRA, La Rochelle, France, 1. 
Szendrö, Z. S., Palos, J., Radnaii, I., Biro-Nemeth, E., \& Romavari, R. (1996). Effect of litter size and birth weight on the mortality and weight gain of suckling and growing rabbit (pp. 365-369). In Proc. $6^{\text {th }}$ World Rabbit Congress, World Rabbit Science Association, Toulouse, France.

Szendro, Z. S., Milisits, G., Papp, G. Y., Gyarmati, T., Lévai, A., Radnai, I., \& Bironé, N. E. (1998). Milk intake and weight gain of rabbits suckled by one or two does (pp. 35-39). In Proc. 10 Nyultenyésztési Tudomànyos Nap, Kaposvàr, In Hung.

Vásquez, R., Petersen, J., \& Mennicken, L. (1997). Der Einfluss alters der Häsin sowie deren Milchleistung und des Geburtsggewichtes von Jungkaninchen auf deren Entwicklung während der Mastperiode (pp. 18-23). In Proc. 10th Symposium on Housing and Diseases of Rabbits, Celle.

Vallet, K. L., \& Christenson, R. K. (1993). Uterine space effects placental protein secretion in swine. Bio. of Rep. 8, 575-584. Retrieved from http://www.biolreprod.org/content/48/3/575.full.pdf + html

Webel, S. K., \& Dziuk, P. J. (1974). Effect of stage of gestation and uterine space on prenatal survival in the pig. $J$. of Anim. Sci., 38, 960-963. Retrieved from http://jas.fass.org/content/38/5/960.full.pdf + html

Wirth-Dzieciolowska, E. M. (1987). Survival of embryos in relation to vasculature of implantation places in laboratory mice. Genetica Polonica, 28, 127-130.

Wu, M. C., Hentzel, M. D., \& Dziuk, P. J. (1987). Relationships between uterine length and number of fetuses and prenatal mortality in pigs. J. of Anim. Sci., 65, 762-770. Retrieved from http://jas.fass.org/content/65/3/762.full.pdf + html

Zerrouki, N., Kadi, S. A., Lebas, G., \& Bolet, G. (2007). Characterization of a Kabylian population of rabbits in Algeria: Birth to winning, Growth performance. World Rab. Sci., 15, 111-114. Retrieved from http://www.wrs.upv.es/files/journals/5.zerrouki(111-114).pdf 